\title{
Empowerment Potentials Of Coffee Farmers By Agroindustry Practitioners Of Coffee Perfume In Kerinci Regency
}

\author{
Sri Wahyuni, Hery Bachrizal Tanjung, Yenny Oktavia \\ Department of Agribusiness, Faculty of Agriculture, Andalas University, Padang, West Sumatra, 25163, Indonesia
}

\section{Article Info}

\section{Received:}

29 November 2019

\section{Accepted:}

04 February 2020

Published:

29 February 2020

\section{Competing Interest:}

The authors have declared that no competing interest exists.

\section{Corresponding Author:}

Sri Wahyuni, Department of

Agribusiness, Faculty of Agriculture, Andalas University, Padang, West

Sumatra, 25163, Indonesia

Email: bbtanjung25@yahoo.com

(C) 2020 The Authors. This is an open access article under the CC BY license.

\begin{abstract}
Empowerment activities to improve the ability of coffee farmers in the Kerinci Regency are very important to be implemented. The purposes of this study are to describe the empowerment activities undertaken by coffee perfume agroindustry practitioners towards coffee farmers in Kerinci Regency and to explain the empowerment potentials of coffee farmers performed by coffee perfume agroindustry practitioners in Kerinci Regency. This research was designed qualitatively with descriptive methods. Data was collected using a focus group discussion (FGD) method with the informants selected in this study as many as 16 coffee farmers and Kerinci Coffee Perfume entrepreneurs themselves. Data analysis was performed using the Miles and Huberman method. The results showed that the empowerment activities carried out by coffee perfume agroindustry practitioners for coffee farmers in Kerinci Regency were still not available, because kerinci coffee perfume agroindustry practitioners only provided training to coffee farmers working in coffee farms owned by the agro-industry entrepreneurs. Meanwhile, the potential for empowerment of coffee farmers by coffee perfume agro-industry practitioners in Kerinci Regency is very high, because of the characteristics of coffee farmers that have the sense to develop and easily receive information to improve their abilities and skills in producing high-quality coffee beans. Based on this, henceforth, this research can be directed at the strategy of empowering coffee farmers in Kerinci Regency by kerinci coffee perfume agro-industry practitioners and the impact of empowerment that has been done.
\end{abstract}

Keywords: agro-industry, coffee, coffee perfume, farmers. 


\section{Introduction}

The agriculture, forestry and fisheries sectors have quite an important role in economic activities in Indonesia, as seen from its contribution to the Gross Domestic Product (GDP) which is quite high at around $13.14 \%$ in 2017 or ranks second after the Manufacturing Industry sector. At the time of the economic crisis, the agricultural sector was a sector that was strong enough to deal with economic shocks and turned out to be reliable in the recovery of the national economy (BPS, 2018).

One of the agricultural sub-sectors that is able to survive amid the crisis is the plantation sector. The sub-sector with considerable potential in contributing GDP in Indonesia is the plantation sector, which is around $3.47 \%$ in 2017 or is the first in the Agriculture, Animal Husbandry, Hunting and Agricultural Services sectors. BPS (2018) also mentions that this sub-sector is a provider of raw materials for the industrial sector, employment, and foreign exchange earners.

One type of estate crops that has a strategic role is coffee. Indonesia is one of the biggest coffee producers in the world after Colombia. Fourth place according to data from the International Coffee Organization (ICO) in 2016, Indonesia has produced 600 thousand tons with a percentage of $6.6 \%$ of the total number of the world's coffee. Of the total production, around $67 \%$ of coffee is exported while the rest $(33 \%)$ meets domestic needs (AEKI 2012). The Ministry of Agriculture's PPHP Directorate General (2012) states that high demand from the world market for Indonesian coffee can be seen from the total coffee exports (beans and processed) in 2017 of 467.8 thousand tons with a value of US \$ 1,187 million which is marketed to 65 export destination countries.

The strategic role of coffee besides being a foreign exchange earner is also because it is a sector that absorbs labor. The majority of coffee plantations are nationally managed by the people so that many people are involved in them. According to data from AEKI (2014), the total area of Indonesian coffee plantations currently reaches 1.2 million hectares. Of the total area, $96 \%$ is smallhorder coffee plantation land and the remaining $4 \%$ belongs to private and Government plantations (PTP Nusantara). Therefore, Indonesian coffee production is highly dependent on smallholder plantations.

Coffee also plays a role in the development of industries ranging from home industry processed coffee industry, middle class to high classes and in increasing revenue. The processed coffee and coffee beans industry also has the ability to increase labor income in all industries. The induction effect of labor income in the coffee and processed coffee industry on other industries is around 1.6 times. Even so, the coffee and processed coffee industry has a limitation in power of backward distribution that is higher than power of future distribution, so that the growth of this industry depends more on the growth of the national economy.

According to Badan Pusat Statistik (2018) that until 2017, the total area of coffee plantations in Indonesia is $1,251,703$ hectares. One of the leading coffee producing regions in Indonesia is the province of Jambi. BPS (2018) states that in 2017 the area of coffee plantations in Jambi Province is 27,446 hectares with a total production of 14,034 tons (BPS, 2017). Jambi is the only province that has three different coffee variants, namely Arabica coffee in Kerinci and Sungai Penuh, Robusta in Merangin, and Tungkal Liberika coffee.

Coffee Statistics Data released by BPS (2018) shows that most or more than $95 \%$ of coffee production in Jambi Province is produced from smallholder plantations. In 2018, coffee from smallholder plantations will cover 26,446 hectares with a total production of 14,034 tons. Sharing these facts shows that Jambi Province has great potential to continue to develop the coffee plantation subsector.

Coffee plantations in Kerinci Regency are cultivated by many smallholder coffee farmers, this has several problems and obstacles. Hasan et al. (2018) and Fadhil et al. (2017) states that most of the coffee produced from smallholder plantations, especially those managed by individuals without involving groups, has a low quality. Technical problems such as lack of water supply which causes lower quality of coffee produced by farmers also becomes a serious obstacle. Another problem is the level of knowledge and skills of farmers who are still low and limited in processing coffee properly and appropriately according to standard operating procedures, both at the time of cultivation, harvest, until post-harvest (Malasari et al., 2017; Zakaria et al., 2017).

The same thing happened with coffee farmers in Jambi Province. The low knowledge of the community in the processing of farming, harvesting, and post-harvest causes low quality of coffee, so the prices obtained are also lower and the farmers' market is limited to middlemen or collectors. Therefore, it is necessary to empower efforts through systematic and intensive extension activities to improve the skills of coffee farmers in Jambi Province in coffee management at the appropriate stages of cultivation, harvesting, and post-harvest according to standard operating procedures, so that the quality of coffee beans produced for sale becomes better and farmers also get incentives in the form of higher prices, and have a wider and unlimited markets.

Kerinci coffee perfume owners consider it necessary to empower smallholder coffee farmers through diversification of processed coffee products in the form of Coffee Perfumes. The emergence of 
the diversification of processed coffee products in the Kerinci Regency in a form of the Kerinci Coffee Perfume agroindustry business product opens new market opportunities for coffee farmers. The quality of coffee beans needed by the perfume coffee agroindustry is a type of arabica coffee, red plucked and dried in accordance with Indonesian national standards. This is done so that smallholder coffee farmers realize the importance of maintaining the quality of coffee beans so that they make changes and apply cultivation, harvesting, and post-harvest patterns in accordance with standard operating procedures in order to get better quality to meet the Kerinci Coffee Perfume agroindustry business supply.

Based on the background of the problems that have been revealed before, the authors conducted a study entitled " Empowerment Potentials Of Coffee Farmers By Agroindustry Practitioners Of Coffee Perfume In Kerinci Regency". The aim of this study are:

1) To know empowerment activities that has undertaken by coffee perfume agroindustry practitioners towards smallholder coffee farmers in Kerinci Regency.

2) To know potential empowerment for smallholder coffee farmers that has performed by coffee perfume agroindustry practitioners in Kerinci Regency.

\section{Materials and Methods}

This research was conducted in June to August 2019 in Kerinci Regency, Jambi Province, which was determined purposively, with the reason that Kerinci Regency is an area that produces Kerinci Coffee Perfume. This study was designed qualitatively to describe the potential empowerment of smallholder coffee farmers in meeting the kerinci coffee perfume agro-industry business supply. The data collection method used in this study is the focus group discussion (FGD) method which aims to explore specific issues related to the potential empowerment of smallholder coffee farmers in Kerinci Regency by the Kerinci coffee perfume agroindustry (Paramita and Kristiana, 2013). The informants in this study were selected purposively, as many as 16 smallholder coffee farmers in Kerinci Regency who supplied coffee beans for the Kerinci Coffee Perfume agroindustry business and Kerinci Coffee Perfume entrepreneurs themselves.

Data collection techniques in this study were carried out by the in-depth interviews (in-depth interviews), observation, and documentation studies; so the type of data in this study consisted of primary data obtained from FGDs, questionnaires containing the characteristics of individual farmers, and interviews with informants, and secondary data obtained from documents supporting the research objectives. Quantitative data analysis in the form of individual characteristics of farmers is processed using a frequency description table. Qualitative data analysis is performed using the Miles and Huberman method, which suggests that the activities in qualitative data analysis are carried out interactively and continue continuously until completion, until the data is saturated. Activities in data analysis are data reduction, data display, and conclusion drawing / verification (Sugiyono, 2012).

\section{Results and Discussion}

\section{Individual Characteristics of Smallholder Coffee Farmers}

The individual characteristics of smallholder coffee farmers in Kerinci Regency are personality traits that are inherent in every individual smallholder coffee farmer from birth, and are also influenced by the environment in which they grow and develop. The individual characteristics of smallholder coffee farmers in the study consisted of age, level of formal education, coffee farming experience, main occupation, land ownership status, land area, and gender. Table 1 shows the characteristics of smallholder coffee farmers in Kerinci Regency.

Table 1 shows that generally smallholder coffee farmers in Kerinci Regency are in the age range of adults (30-49 years) to old ( $>50$ years), where most of them are male. Old age farmer is generally assumed by decreasing one's productivity because the older a person is, the more difficult it will be to receive information and adopt technology (Riana et al., 2015; and Sadono et al., 2014). However, field observations supported by Saragih's research results (2017) show the opposite, where the age of farmers does not have a real influence on the increase in farmers' coffee production and the ability of farmers to process coffee beans. The age of the farmer does not affect the ability of farmers to receive information, motivation of farmers, or the ability of farmers to do farming and processing post-harvest coffee.

Generally, coffee farmers have a high level of formal education, which is between high school to college or bachelor. Education influences the way and thinking of farmers, because education is a process of developing farmers' knowledge, skills and attitudes that is carried out in a planned manner, so as to obtain changes in life improvement. The higher the level of one's education, the more thought patterns develop so that they can easily make decisions in doing things well including decisions in coffee farming activities.

Generally the main work of these farmers is coffee farming with experience in coffee farming ranging from new (1-3 years) to old (more than 7 years). This shows that generally coffee farmers in Kerinci Regency are no longer new farmers with modest abilities and experience. The age of farmers who are already mature and old, supported by long- 
standing coffee farming experience and a high level of formal education, is one of the great potentials for increasing the knowledge and skills of coffee farmers in Kerinci district through empowerment activities by various parties.

Table 1.Characteristics of Coffee Farmers

\begin{tabular}{|c|c|c|}
\hline Individual Characteristics & Frequency (numbers of people) & Percentage $(\%)$ \\
\hline \multicolumn{3}{|l|}{ Age } \\
\hline Young (<30 tahun) & 0 & 0,0 \\
\hline Adult (30-49 tahun) & 6 & 37,5 \\
\hline Old ( $\geq 50$ tahun) & 10 & 62,5 \\
\hline \multicolumn{3}{|l|}{ Formal Education } \\
\hline Low (SD) & 2 & 12,5 \\
\hline Moderate (SMP) & 3 & 18,8 \\
\hline High (SMA-Sarjana) & 11 & 68,8 \\
\hline \multicolumn{3}{|l|}{ Coffee Farming Experience } \\
\hline New (1-3 tahun) & 7 & 43,8 \\
\hline Moderate (4-6 tahun) & 3 & 18,8 \\
\hline Long ( $\geq 7$ tahun) & 6 & 37,5 \\
\hline \multicolumn{3}{|l|}{ Main Occupation } \\
\hline Coffee farmers & 15 & 93,8 \\
\hline Others & 1 & 6,3 \\
\hline \multicolumn{3}{|l|}{ Land Ownership Status } \\
\hline One’s Own Property & 16 & 100,0 \\
\hline Rent & 0 & 0,0 \\
\hline \multicolumn{3}{|l|}{ Land Area } \\
\hline Narrow (0.5-1.5 ha) & 10 & 62,5 \\
\hline Moderate $(1.6-2.9 \mathrm{ha})$ & 1 & 6,3 \\
\hline Large ( $\geq 3$ ha) & 5 & 31,3 \\
\hline \multicolumn{3}{|l|}{ Gender } \\
\hline Male & 11 & 68,8 \\
\hline Female & 5 & 31,3 \\
\hline Total & 16 & 100,0 \\
\hline
\end{tabular}

(Source: questionnaire of farmer's characteristics)

Furthermore, Table 1 also shows that farmers' land ownership by farmers is generally their own land with land area generally ranging between $0.5-1.5$ hectares. This also has its own potential to further develop coffee farming in Kerinci District, because farmers' land area, which generally ranges from more than 1 hectare and private ownership, makes farmers more free to implement the various treatments needed to improve their coffee farming. According to Narti (2015) this requires counseling in a holistic manner, synergy between parties, coordination, focus and measurability.

\section{Empowerment activities by coffee perfume agroindustry practitioners for smallholder coffee farmers in Kerinci Regency}

Suharto (2010) states that empowerment is a process and a goal. As a process, empowerment is a series of activities strengthening the power and empowerment of weak groups in society, including individuals who experience poverty problems. As a goal, empowerment refers to the state or results achieved by a social change that is a community that is empowered, has the power or knowledge and the ability to understand their life needs. Sumarti et al. (2017) states that success in community empowerment can be seen from their empowerment concerning economic capacity, ability to access welfare benefits, and cultural and political abilities. These three aspects are related to the four dimensions of power, namely: power within, power to, power over, and power with.

As with other aspects of farming, coffee farming also requires a touch of counseling and empowerment by various parties for the development of their farming. Various findings state that there are quite a number of obstacles in coffee farming, especially in terms of the low quality and quality of coffee by smallholder coffee farmers which has an impact on the low selling price of coffee beans, as well as findings by Hakim (2003), Malasari et al., (2017) ; Zakaria et al., (2017).

Recently, coffee perfume has become one of the most promising diversified coffee products. In the market, has developed various types of coffee 
perfume products such as Bali Coffee Perfume, Coffee Perfume Ou, and so on. Kerinci Coffee Perfume as one of the processed coffee perfume products with raw materials of Arabica and Robusta beans grown in Kerinci Regency, has very promising potential. The existence of coffee perfume agroindustry as a new business is expected by the surrounding community, especially smallholder coffee farmers in Kerinci Regency to increase the selling opportunities of farmers coffee beans, especially because coffee perfume agroindustry entrepreneurs buy coffee beans at a price higher than the market price normally accepted by farmers, with requirements must meet quality in accordance with applicable operational standards.

Based on the findings through in-depth interview in the field, the kerinci coffee perfume agro-industry entrepreneur not only acts as a buyer of farmers' coffee beans, but also as a facilitator in empowering smallholder coffee farmers. Kerinci coffee perfume entrepreneurs provide counseling and training regarding standard operational procedures for processing good and quality coffee beans. This is certainly not only beneficial for coffee perfume entrepreneurs to get quality coffee beans, but also very profitable for coffee farmers because they gain knowledge and skills that are very useful to improve the quality of their coffee beans.

However, the results of the FGD continued to include smallholder coffee farmers, it is known that generally coffee farmers in the vicinity of the coffee perfume agroindustry do not all get empowerment from coffee perfume agroindustry entrepreneurs. Coffee farmers generally increase their knowledge through self-taught learning via the internet and YouTube

This shows that, coffee farmers in Kerinci Regency have not received maximum support, especially from the government. In fact, farmers need support, especially improving the ability and skills in processing their farming and crop yields to produce quality coffee beans.

Based on this, it can be seen that in its implementation, the empowerment activities carried out by coffee perfume agroindustry entrepreneurs have not touched the smallhorders coffee farmers in Kerinci Regency, especially the smallholder coffee farmers around the coffee perfume agroindustry. The empowerment carried out by coffee perfume entrepreneurs is only limited to farmers who work in the coffee plantations of the entrepreneurs themselves. Therefore, community coffee farmers in Kerinci Regency generally have never received counseling and empowerment from any party.

In fact, by carrying out sustainable empowerment activities based on the needs, abilities and skills of farmers will increase rapidly, as well as the findings of Sarirahayu and Aprianingsih (2018) which states that intensive and ongoing training of smallholder coffee farmers can improve their abilities. By using the right empowerment strategy, smallholder coffee farming will experience development and the ability of farmers in processing coffee beans according to standards will increase. Zakaria et al. (2017) shows that some strategies that can be used for this are developing agricultural product processing, improving technical skills of farming to improve product quality, empowering farmer groups to further improve their business. Related to this, the results of Apsari et al. (2017) also shows that farmers' training in the form of coffee processing and adequate packaging will be able to increase the capacity of coffee farmers.

\section{Potential empowerment by smallholder coffee farmers by coffee perfume agroindustry practitioners in Kerinci Regency}

Based on the summary of several experts and literature, in the results of his study Laily et al. (2014) mentioned concluding empowerment is a collaborative process, where clients and social workers work together as partners. Empowerment is an effort to obtain resources and the ability to use these resources in an effective way, where the empowerment process is a dynamic process, synergy, always changing and evolving, because problems always have many ways of solving. Empowerment can be achieved through the equalization of personal structures and socio-economic development.

The findings in the field show that generally smallholder coffee farmers in Kerinci Regency, especially coffee farmers around the Kerinci coffee agro-industry, still have not received counseling and training from any party. The results of the FGDs showed that the agriculture or plantation service at the district and provincial level had not yet come to inspect their location. Counseling and training activities have not been carried out, and no program and assistance has been touched by the government. Coffee cultivation and yield processing are carried out based on knowledge gained and studied through years of experience. In addition, farmers are also quite active in finding information either through peers, neighbors, to literacy through the internet, and social media such as YouTube.

Smallholder coffee farmers in Kerinci Regency also do not have a group, so generally they do everything themselves, from cultivation, use of tools, harvesting, post-harvest, storage, to marketing. In fact, the area of coffee farming in the area around the coffee agro-industry is quite extensive and promising.

In addition, the farmers' curiosity and strong motivation to advance in improving their skills are other important fpractitioners for the potential empowerment of farmers in Kerinci Regency. This is evident from the recognition of one of the farmers who had also previously been mentioned, that he was looking for ways of processing coffee that is in accordance with standards to produce quality coffee 
beans through social media, especially YouTube. The farmers are also diligent in reading, listening and discussing related to good coffee cultivation and post-harvest processing that is in accordance with standards to produce good coffee beans.

These findings are a positive indication that there is great potential for empowering smallholder coffee farmers to improve their abilities. The absence of those who do this can be an opportunity for coffee perfume agroindustry to develop farmers around the agroindustry location. This not only has a positive impact on improving the ability of coffee farmers to produce quality coffee beans which results in an increase in product selling prices, but also is beneficial for coffee agro-industry businesses in getting raw materials in the form of quality coffee beans as expected and closer to the location effort. This of course will further minimize costs, especially transportation costs.

Parson et al. (1994) cited by Suharto (2010), have mentioned that there are three empowerment strategies, micro, mezzo, and macro scale. Related to the potential empowerment of smallholder coffee farmers carried out by coffee perfume agro-industry practitioners, as an initial step, empowerment can be done on a micro scale, namely conducting counseling, increasing knowledge, and training for coffee farmers. The results of observations in the field and the results of discussions through FGD with farmers showed that farmers are not laggard or final followers if they are involved in the process of adopting an innovation. Initiative of farmers in finding their own information, learning independently, and in-depth discussions among themselves shows that smallholder coffee farmers in Kerinci Regency are the types of farmers who have great potential to be developed through intensive empowerment programs because they can easily receive new information and innovations. can improve their abilities.

\section{Conclusions}

The empowerment activities carried out by coffee perfume agroindustry practitioners for smallholder coffee farmers in Kerinci Regency were still not available, because kerinci coffee perfume agroindustry practitioners only provided training to coffee farmers working in coffee farms owned by the agroindustry entrepreneurs. Meanwhile, the potential for empowerment of smallholder coffee farmers by coffee perfume agro-industry practitioners in Kerinci Regency is very large, because the character of coffee farmers who want to develop and easily receive information to improve their abilities and skills in producing quality coffee beans. Based on this, henceforth, this research can be directed at the strategy of empowering smallholder coffee farmers in Kerinci Regency by kerinci coffee perfume agroindustry practitioners and the impact of empowerment that has been done.

\section{Acknowledgments}

Thank you to the primarily directed at the Faculty of Agriculture, the University of Andalas as funders of research conducted by the author.

\section{References}

[1] [AEKI] Asosiasi Eksportir Kopi Indonesia. (2014). Industri Kopi Indonesia. Internet. http://www.aekiaice.org/page/industri-kopi/id (diaksespada 20 Mei 2019).

[2] Apsari, N.C., Gutama, A.S., Nurwati, N., Wibowo H., Humaedi, S. (2017). Pemberdayaan Petani Kopi Melalui Penguatan Kapasitas Dalam Pengolahan Hasil Kopi Di Desa Genteng, Kecamatan Sukasari, Kab. Sumedang. Jurnal Penelitian dan PPM. 4, (2), 129-389.

[3] [BPS] Badan Pusat Statistik. (2018). Statistik Kopi Indonesia 2017. Indonesia: Badan Pusat Statistik.

[4] Fadhil, R., Maarif M.S, Bantacut T, Hemawan, A. 2017. Strategi Pengembangan Sumber Daya Manusia Agroindustri Kopi Gayo dalam Menghadapi Masyarakat Ekonomi ASEAN. Jurnal Manajemen Teknologi. 16, (2), 141-156

[5] Hasan, A., Amaliah, I, Riani, W. (2018). Model Pemberdayaan Usaha Kopi Rakyat di Desa Pangadegan Kecamatan Rancakalong Kabupaten Sumedang. Prosiding Ilmu Ekonomi. 4, (1), 9-16.

[6] Laily, S.F.T., Ribawanto, H., \& Nurani, F. (2014). Pemberdayaan Petani Dalam Meningkatkan Ketahanan Pangan (Studi di DesaBetet, Kecamatan Ngronggot, Kabupaten Nganjuk). JAP. 2, (1), 147-153.

[7] Malasari, W., Banowati, E, Hariyanto. (2017). Pemberdayaan Masyarakat Petani Kopi Dalam Upaya Meningkatkan Kuantitas Komoditas Kopi Gunung Kelir. Geo Image. 6, (2), 123-130.

[8] Narti, S. Hubungan Karakteristik Petani Dengan Efektivitas Komunikasi Penyuluhan Pertanian Dalam Program SL-PTT (Kasus Kelompok Tani di Kecamatan Kerkap Kabupaten Bengkulu Utara). Profesisonal FIS UNIVED. 2, (2), 40-52.

[9] Paramita, A., \& Kristiana, L. (2013). Focus Group Discussion Dalam Penelitian Kualitatif. Penelitian Sistem Kesehatan. 16, (2), 117-127.

[10] Riana, Purnaningsih, N, Satria, A. (2015). Peranan Penyuluh Swadaya dalam Mendukung Intensifikasi Kakao di Kabupaten Sigi Provinsi Sulawesi Tengah. Penyuluhan. 11, (2), 201 - 211.

[11] Sadono, D, Sumardjo, Gani, D.S, Amanah S. (2014). Farmer Empowerment in The Management of Rice Farming in Two Districts in West Java. Journal of Rural Indonesia. 2, (1), 105126.

[12] Saragih, J.R. (2017). Aspek Sosioekologis Usahatani Kopi Arabika di Dataran Tinggi Kabupaten Simalungun Sumatera Utara. Sosiohumaniora. 19, (3), 253-259.

[13] Sarirahayu, K., \& Aprianingsih, A. (2018). Strategy for Improving Smallholder Coffee Farmers Productivity. The Asian Journal of Technology Management. 11, (1), 1-9.

[14] Suharto, E. (2010). Membangun Masyarakat Memberdayakan Rakyat: Kajian Strategis Pembangunan Kesejahteraan Sosial \& Pekerja Sosial. Bandung: PT Refika Aditama.

[15] Sugiyono. (2012). Metode Penelitian Kuantitatif Kualitatif dan R \& D. Bandung: Penerbit Alfabeta.

[16] Sumarti, T. Rokhani, Falatehan, S.F. (2017). Strategi Pemberdayaan Petani Muda Kopi Wirausaha di Kabupaten Simalungun. Penyuluhan. 13, (1), 31-39. 